\title{
Disputes and Reflections on Implementing Creative Entrepreneurial Education in Colleges and Universities
}

\author{
Lu Haochuan \\ School of Management, Wuhan University of Technology, Wuhan Hubei Province, China, 430070 \\ Email: 645154814@qq.com
}

Keywords: Disputes and Reflections; Creative Entrepreneurial Education; Colleges student; trend

\begin{abstract}
In nowadays, creative entrepreneurial education becomes the main trend for the education reform in higher vocational colleges and development in the future. Higher vocational colleges need to update educational ideas, change teaching method, advance with the time and implement creative entrepreneurship into each education process continuously if they want to cultivate creative entrepreneurial talents. They can explore effective ways for cultivation, deepen and reform talent training system actively through reflections.
\end{abstract}

\section{Introduction}

It needs to carry out the education policy of the party comprehensively, implement the crucial task of establishing moral values and cultivating people, be based on the talent training target of school for "engineering elite and backbone of the society", insist on the implementation principles of "education oriented, professional integration, collaborative promotion and connotation development", run creative entrepreneurial education through the whole process of talent training, penetrate into every teaching process, promote the innovation of talent training model, speed up to cultivate more creative entrepreneurial talents with coordinated development among knowledge, ability and quality, creative spirit and participating into practice bravely, which can provide powerful talent intelligent support for the country to implement creation-driven development strategy and promote the upgrading for economic quality and efficiency.

\section{The importance of performing creative entrepreneurial talent training in higher vocational colleges}

Cultivating creative entrepreneurial talent is the demand of social economy development.

China is with a great population and belongs to developing country. It does not develop in a balanced way with a great population, so under the current new trend, it needs to change the social economic development method, speed up creative construction, encourage and support national innovation and promote our social and economic development. Students at higher vocational colleges are with excellent practical and hands-on performance and they are also with good creative entrepreneurial conditions. But in view of the practical situation, the creative entrepreneurship rate of our students from higher vocational colleges is very low. The employment of students from higher vocational colleges can only be well guided by strengthening creative entrepreneurship and cultivating creative entrepreneurial talents.

Cultivating creative entrepreneurial talent is the demand of students from higher vocational colleges to realize the value of life. As our country is upgrading industry structure and changing economic development method continuously, it requires a lot of compound talents and skilled talents. The professional quality, knowledge and skills of most students from higher vocational colleges can't meet the requirements of the employers. Students from higher vocational colleges need to master the practice skills, improve theoretical knowledge level and possess creative consciousness and spirit and then attain successful career in entrepreneurship. Strengthening the training for creative entrepreneurship among students in higher vocational colleges is good for expanding the employment ideas of students, setting up creative spirit and changing employment 
concept.

\section{Measures taken by colleges and universities to implement creative entrepreneurial education}

First, professional teaching content should not limit itself to the textbook. It needs to make corresponding adjustment and expansion by following up with the time closely. Professional teachers need to have an adequate understanding of new technology, new process and new equipment and deliver the frontier trends and information of professional technology to the students timely. The projects, cases and carriers adopted in professional teaching are from real production practice. Professional teachers need to follow up the development of new technology, update teaching content continuously and try to introduce technologies is adopting and going to adopt in production in short time as well as problems existed in current technologies into the classroom teaching.

Second, teaching methods need to be flexible, teaching means need to be diversified and then realize the innovations for teaching methods and means. For example, it can adopt "heuristic teaching method", "inquiry teaching method", "collective discussion method", "excellent student demonstration method" and "cooperative teaching and learning" and so on to introduce interactive platform between teacher and student with the help of network resources and multimedia means, so that transfer the education from traditional teacher center, classroom center and knowledge center into student center, practice center and capacity center.

Third, the evaluation method for students needs to be comprehensive and three-dimensional. Don't take the examination score as the only standard of measuring the learning results of students. For example, the composition of professional course achievement can adopt the mode of examination $50 \%$ + class $10 \%$ + homework $20 \%$ + innovation $20 \%$. The homework can be assigned in way of comprehensive analysis, research report, information searching and design scheme etc. Take the creative capacity into evaluation and ensure the learning achievement of students only good at memorizing book knowledge mechanically does not exceed good, which can inspire the innovation desire of students.

Last, colleges and universities need to provide institutional guarantee for promoting the implementation of science and technology activities and cultivating scientific research ability of students. Colleges and universities should set up "Leading Group for Extracurricular Science and Technology Activities for Students at Colleges and Universities" composed of related school leaders as well as personnel from youth league committee, research department, office of academic affairs, financial department and library etc. Set up organizing committee office in school league committee generally and plan and implement science and technology innovation activities among students comprehensively. Each school has set up corresponding working group to cooperate with organization specifically. Employ internal and external experts and professors to compose guidance and review committee for the extracurricular science and technology activities among students and they will be responsible for the guidance and review work for extracurricular science and technology activities among students. At the same time, it needs to publish related system, such as "Implementation Methods for Colleges and Universities Organizing Students to participate in "Challenge Cup" College Student Entrepreneurship Program and Extracurricular Science and Technology Works and other Competitions" and "Management Methods of College Student Research Fund" etc. Each school and department should establish corresponding organization institutions for students' science and technology academic competitions and form work system with emphasis from both party and government and collaborative cooperation and management among different parties. Meanwhile, it needs to emancipate the mind, expand the application objects for student research fund, and broaden the sources of fund, form complete program recommendation, application, fund distribution, review and reward system and treat the student research fund management as a long-term cause carefully.

It needs to set up research-based teaching certification standards, implement flipped classroom, mixed classroom and other teaching modes, promote MDP teaching mode reform (MOOC before class, Discuss in Class and Project after class), transfer the teaching mode focusing on knowledge 
imparting into research type, heuristic and independent learning model, cultivate teamwork spirit of students, inspire the enthusiasm of independent research and active learning and strengthen the cultivation for learning ability, creative consciousness, creative thinking and entrepreneurial quality of students. It also needs to encourage the teachers to integrate the international frontier academic development, latest research results and practical experience into classroom teaching while imparting knowledge, guide the students to discover problem, study problem and solve problem independently with organic combination of learning, research and practice, accumulate knowledge, train ability and exercise thinking in research and then inspire the entrepreneurial inspiration of students.

\section{Exploration of constructing creative entrepreneurial talent training system in higher vocational colleges}

Change old ideas and reform the traditional way of talent training

Our country insists on talent training way of "employment oriented" for a long time, which causes the employment dilemma faced by students from higher vocational colleges. Traditional talent training model takes current employment requirements into account but does not put emphasis on training the ability of students for development in the future. No matter at home or at school, it lacks the training for creative entrepreneurship spirit and creative consciousness for students, which will weaken the ability of students for dealing with the market change in their future development process. Therefore, it needs to change the old ideas timely, develop creative entrepreneurial education model, confirm the talent training system of constructing creative entrepreneurial talents in higher vocational colleges with training objectives and cultivate the creative consciousness, creative spirit and courage for entrepreneurship.

Strengthen to construct creative entrepreneurial education courses and build up theoretical basis for creative entrepreneurship

It needs to involve creative entrepreneurial courses into professional education plan and strengthen to construct multi-layer creative entrepreneurial education courses. The setting of creative entrepreneurial education courses should combine professional curricular system; in addition, creative practice activities also need to be combined with professional practice subject, highlight professional characteristics, strengthen to train creative entrepreneurial talents, promote training mode for creative entrepreneurial talents and reform teaching content and curriculum system continuously. For the cultivation of creative entrepreneurial talents in higher vocational colleges, it not only needs to reform teaching content continuously, but also needs to emphasize the comprehensiveness of practice and theory. Therefore, it also needs to make continuous reforms for teaching method; at the same time, reform traditional examination system vigorously. It should not use the examination to check the future of the student. Make comprehensive evaluation for students through various channels, such as paper, research and competition etc.

Strengthen to build up creative entrepreneurial teacher team, ensure the smooth implementation of training for creative entrepreneurial talents

Building up creative entrepreneurial teacher team is the safeguard means for training creative entrepreneurial talents, which should be supported by higher vocational colleges. It needs to encourage the teachers to exercise in enterprises, participate in social creative entrepreneurship programs and promote the improvement of teachers in paper level and guidance ability, which is also the key for training creative entrepreneurial talents. Higher vocational colleges cooperate with enterprises. They invite successful entrepreneurs to hold seminars at school, so that the students can learn entrepreneurial experience from them and entrepreneurs can also instruct students to make creative entrepreneurship.

Set up creative entrepreneurship platform for students and exercise their entrepreneurship skills

There are a lot of communities in higher vocational colleges and all of them are composed of students with the same interest. Subjective initiative can only be played effectively by respecting the dominant role of students in class, which has a profound influence on the creative entrepreneurship development of students. Communities at higher vocational colleges are inclined 
to cultivate creative and compound talents with high quality. They are leaded by school youth league committee, guided by professional teachers and leaded by school party committee. Build up learning community related to majors and participate in various skill competitions by depending on learning-community. In this way, it is good for training the creative entrepreneurship spirit and entrepreneurship ability of students. In addition, the school encourages teachers to participate in the creative entrepreneurial talents training plan, promotes the ability of students in solving problems and increases employment rate.

\section{"Reflection" on promoting creative entrepreneurial talents training education in higher vocational colleges}

Before cultivating creative entrepreneurial talents in higher vocational colleges, first, it needs to reflect the concept of creative entrepreneurship in narrow sense and broad sense, try to make overall consideration and prepare cultivation system based on our real situation. Second, it needs to "reflect" the objects for creative entrepreneurial education and the objects are students. To make students fully play the dominant role in class, the teachers need to change teaching ideas and teaching methods inappropriately, encourage the students to participate in creative entrepreneurial education and coordinate the local and comprehensive relationship. Third, it needs to "reflect" the philosophy of creative entrepreneurial education. The essence of creative entrepreneurial education needs to be valuable. Prepare education content based on actual situation to meet the demand of training creative entrepreneurial talents. Take value, target and essence as the starting points for higher vocational colleges to cultivate creative entrepreneurial talents. Last, we need to clarify that with what kind of purpose, at which height and based on what kind of realities do we make the creative entrepreneurial education.

Set up incentive policy and system suitable for creative entrepreneurial education

It needs to stipulate the required creative practice credits in professional training program, ensure that each student can accept the basic creative entrepreneurial education and grant suitable credits to students who make excellent performance in discipline competitions and entrepreneurial practice. To relieve the time restriction for students in participating creative entrepreneurial practice, the school will further improve course selection system on the basis of credit system and create convenient conditions for students to extend the schooling time. The teachers are encouraged to participate in creative entrepreneurial education and they will be awarded if they instruct the students to attain excellent achievements.

Explore social resource and set up expert guidance mechanism

It needs to grasp the policy guidance of creative entrepreneurial education accurately, aim at social demand, serve the economic and social development and set up creative entrepreneurial education linkage mechanism with government promotion, school initiative and social interaction; strive for and make use of the government preferential policies actively, implement close cooperation with related government departments and related industry associations and form good economic and social benefit; fully play the talents advantages from government and society and set up expert guidance committee for creative entrepreneurial education. Expert guidance committee provides consultation and guidance for implementing creative entrepreneurial education at school; approves the curriculum setting for creative entrepreneurial education; participates in building up practice base for creative entrepreneurial education out of school; evaluates creative entrepreneurial program; assists to build up relationship with government, enterprises and other social circles. Expert guidance committee for creative entrepreneurial education is composed of school leaders, senior teachers, government officials, famous entrepreneurs and excellent alumni.

\section{Reference}

[1] Guan A H. Reflections of training the creative and entrepreneurial talents by means of the simulation environment on campus[C]// The, International Conference on Computer and Automation Engineering. IEEE, 2010:526-529. 
[2] Miclea M. Institutional Approaches to Entrepreneurialism: Reflections on the Case of "BabeşBolyai" University in ClujNapoca[J]. Higher Education in Europe, 2006, 31(2):105-115.

[3] Gibb A. Creating conducive environments for learning and entrepreneurship: living with, dealing with, creating and enjoying uncertainty and complexity[J]. Industry \& Higher Education, 2002, 16(3):135-148.

[4] Benešová T. Towards Entrepreneurship: Reflections Between Theory and Practice[J]. International Journal of Entrepreneurial Knowledge, 2016, 3(2):5-15.

[5] Wright S L, Katz J A. Protecting Student Intellectual Property in the Entrepreneurial Classroom.[J]. Journal of Management Education, 2016, 40(2). 